\title{
Soil degradation in the Senegal lower valley
}

\author{
Laurent BARBIERO ${ }^{\mathrm{a}}$ and Claude HAMMECKER ${ }^{\mathrm{b}}$ \\ laurent.barbiero@get.omp.eu \\ a Géoscience Environnement Toulouse, Institute de Recherche pour le Développement (IRD), 14 \\ Avenue E. Belin, F-31400 Toulouse, France \\ ${ }^{\mathrm{b}}$ Supagro, Institute de Recherche pour le Développement (IRD), UMR Eco \& Sols, 2 P1 Viala, F- \\ 34060 Montpellier, France
}

The Senegal River is regulated by two dams, the Diama anti-salt dam constructed in 1986, close to the river mouth (Fig. 1), to prevent marine intrusions during high tides, and the Mantanali reservoir dam that was impounded two years later in Mali. Since then, there has been a spectacular development of irrigated agriculture in the valley. The initial plan for development of the Senegal River valley envisaged a potential of at least 250,000 ha, which could be increased to 375,000 ha, mainly in the two countries, Senegal and Mauritania. This intensification of agriculture and the increase in irrigated areas has disrupted the existing environmental balance. It is therefore important to determine whether they have caused soil degradation, or simply offered a new framework for the development and exploration of the Senegal middle valley. Impact studies prior to development are generally insufficient to understand the environment and the complexity of its functioning. As will be shown in this study, recent pedogenetical processes in the Senegal River valley have led to soil diversity and salinity distribution. The first objective is to illustrate the mechanisms that dominated this environment until the commissioning of the two dams. In a second step, we will present the evolution 
of some sites being studied at the beginning of irrigated agriculture, focusing on soil salinisation and alkalinisation hazards.

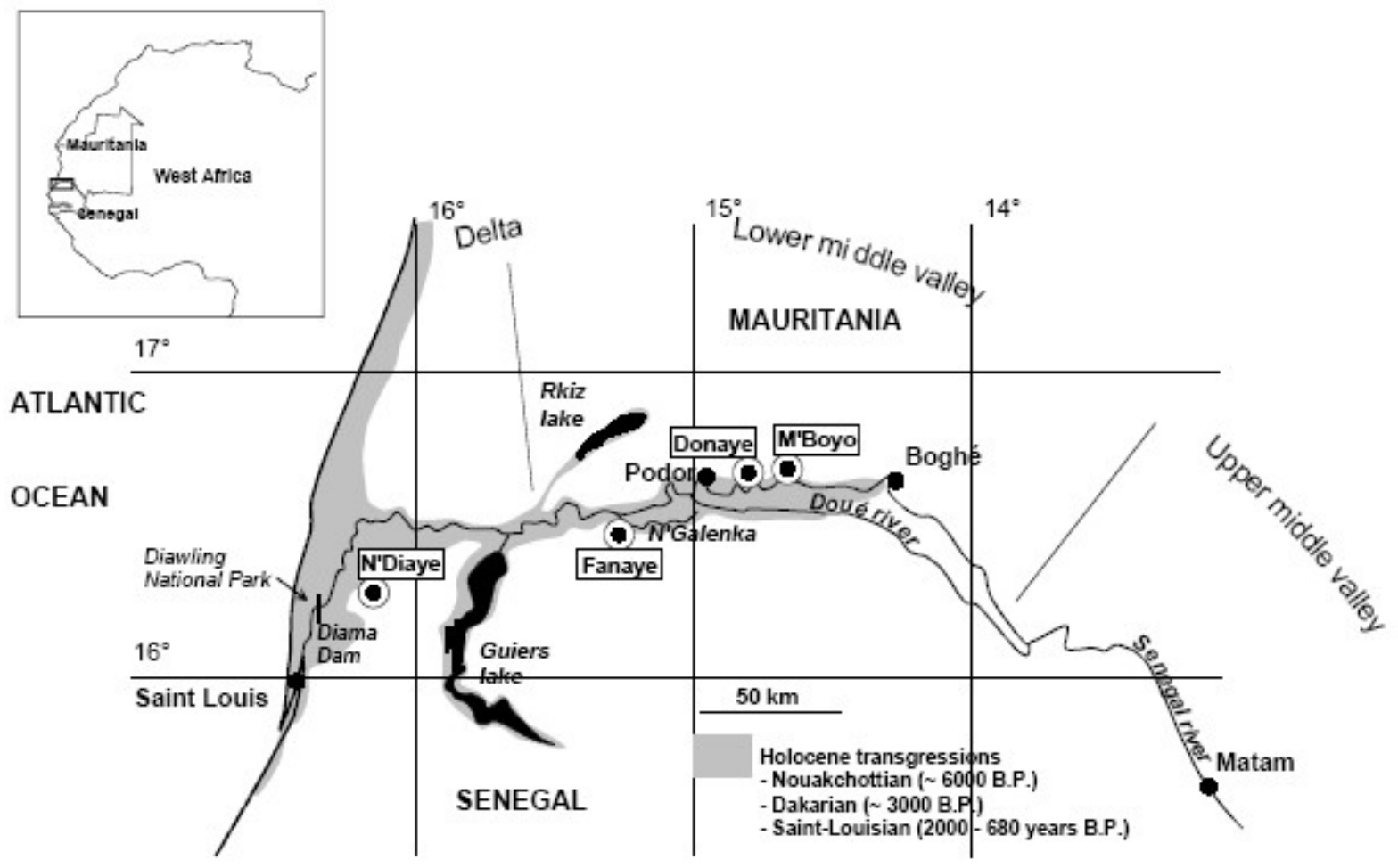

Fig. 1. The Senegal valley, extension of the holocène transgressions and location of the monitored sites.

\section{Generalities and definitions.}

\section{A. Saline soils, salinization process, sodication,}

\section{Alkalization}

A soil is described as saline when the morphological, physico-chemical or agronomic properties of the soil is modified by the presence of significant quantities of soluble salts whether in the soil solution or crystallized. Generally when the electrical conductivity of the soil solution is greater than $0.4 \mathrm{dS} \cdot \mathrm{m}^{-1}$ 
(or mS.cm ${ }^{-1}$ ) the soil is considered saline (Richards 1954). Except in some special cases (Hammecker et al. 2012), saline soils are formed generally in areas with highly evaporative conditions when the water balance has a leaching deficit. During the drying of the soil, water vaporizes and the mineral salts remain in situ and accumulate, generally in the upper part of the soil profile. Saline soils are therefore found mainly in arid zones around the world and particularly in intertropical areas where soil conservation is paramount. The management of this type of soil is a major environmental problem for the development of irrigated agriculture in these arid or semi-arid zones. All types of salinization processes are not equivalent insofar as their effects on soil quality are different and where restoration of initial soil properties is more or less difficult. There are generally three types of processes:

- Salinization process is an excessive accumulation of soluble salts (chlorides, sulphates, carbonates, etc.) in the soil profile which reduces the availability of water to plants by subjecting them to osmotic stress. Depending on the nature of the salts, that is to say they are neutral (chlorides, sulphates, ...) or alkaline (bicarbonates, carbonates, etc.), we can distinguish different evolutions, which will have particular physicochemical consequences .

- Sodication corresponds to an accumulation of sodium on the cationic soil exchange complex. It is manifested by a decrease in the porosity as well as the structural stability of the soils.

- Alkalization is an accumulation of weak acid bases such as bicarbonates which leads to an increase in soil $\mathrm{pH}$. Increasing the $\mathrm{pH}$ can become problematic for plant growth as it can block the uptake of some nutrients. Moreover, the phenomenon of alkalization also accelerates sodication. Indeed, precipitation of calcite $\left(\mathrm{CaCO}_{3}\right)$ enriches the solution of the soil correspondingly in sodium, which therefore preferentially adsorbs onto the exchangeable complex. 


\section{B. The quality of irrigation water}

Evolution of soil physicochemical characteristics and their suitability for cultivation depend directly on the quality of irrigation water. Several indicators have been defined to assess the intrinsic quality of water:

- Electrical conductivity (EC) of water is easy to measure as a field indicator, and is expressed in $\mathrm{mS} . \mathrm{cm}^{-1}$ or dS.m $\mathrm{m}^{-1}$. It is directly related to the total concentration of salts (CTS) in solution which can be determined by the following relationship:

$$
C T S_{\left(\text {mg. } l^{-1}\right)}=0.64 \square 0^{-3} \times C E_{\left(d S . m^{-1}\right)}
$$

- SAR: which corresponds to Sodium Adsorption Ratio is an indicator that attempts to assess the risk of sodium adsorption onto the exchange complex. The SAR is expressed in terms of the concentrations of the different cations in centi-mole-charge per liter of solution. Thus, the higher the SAR of water, the greater is the risk of soil sodication.

Based on these two basic indicators, the Riverside Salinity Laboratory team (1954) of USDA developed a diagram to assess the risks for the soil, when water of a given composition is used for irrigation. The risk of salinization and sodication can thus be determined from EC and SAR values.

However, this representation only gives an instantaneous view of the risks associated with the composition of the solution but does not anticipate its evolution in the event of concentration. As shown in Figure 2, the water composition of Doué is apparently of very good quality for irrigation as it has a low salt concentration, low SAR and is positioned in box C1-S1 indicating low risk of soil degradation. However, when concentration of salts is increased, the composition of Doué water becomes sodic (the SAR increases strongly) and the risk of sodication becomes very high. However, as irrigation is practiced in arid zones with high evaporation demand it is essential to be able to anticipate the composition of irrigation water when it is concentrated and the salt content is increased. 


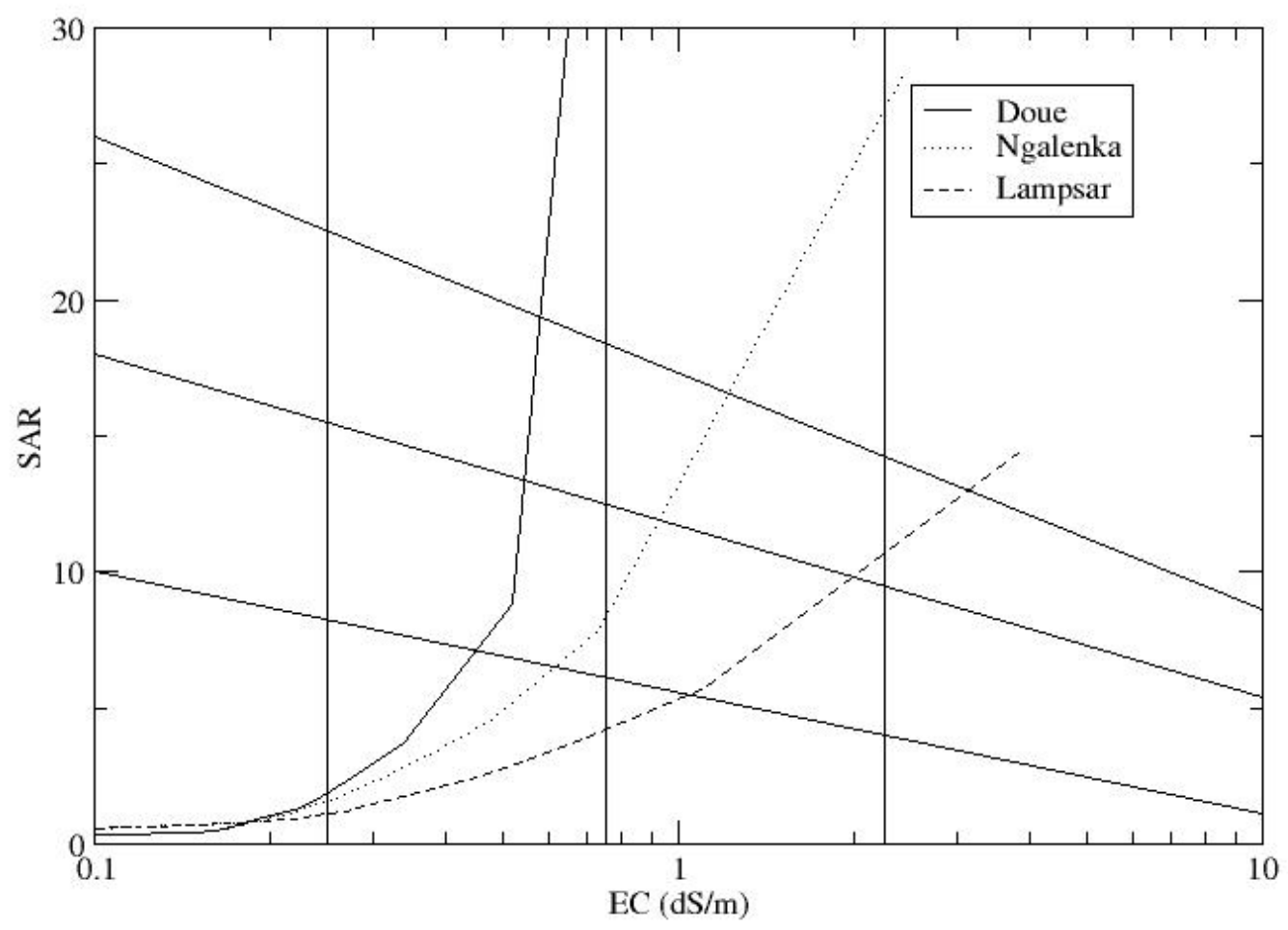

Fig. 2. Chemical Evolution of Senegal river irrigation water in Doué, N'Galenka and Lampsar during evaporation.

Therefore, other indicators are used to qualitatively predict the evolution of the chemical composition of the solution in case of increase in concentration. One of the main indicators being the calcite residual alkalinity $\left(\mathrm{RA}_{\text {calcite}}\right.$, as in natural surface water, alkalinity generally corresponds to the concentration of bicarbonates $\left(\mathrm{HCO}_{3}^{-}\right)$and / or carbonates $\left(\mathrm{CO}_{3}{ }^{2-}\right)$. Upon increase in concentration, calcite $\left(\mathrm{CaCO}_{3}\right)$ is the first mineral to crystalize. Calcite RA can be used to predict whether the solution evolves towards a neutral or carbonated saline condition defined as follows: $\mathrm{RA}_{\text {calcite }}=\mathrm{Alk}$. $\mathrm{Ca}^{2+}$ where the concentrations of alkalinity (Alk) and calcium are expressed in mmol $\mathrm{m}^{-1}$.

- if $\mathrm{RA}_{\text {calcite }}<0$ the solution contains more Ca than alkalinity and during the concentration process, and crystallization of calcite, the solution composition will decline in alkalinity and increase in calcium. Therefore, there is no risk of sodication because calcium is the dominant 
cation in solution and on the exchangeable complex. This condition is sometimes referred to as a "neutral pathway"

- if $\mathrm{RA}_{\text {calcite }}=0$ calcite will precipitate at equilibrium and the $\mathrm{pH}$ of the solution will not exceed 8.5

- if $\mathrm{RA}_{\text {calcite }}>0$ the solution contains more alkalinity than calcium and crystallization of calcite will deplete the stock of calcium. While concentrating, the solution will become more and more alkaline, $\mathrm{pH}$ will increase beyond 8.5 and above all the sodium will become the major cation in solution and on the exchange complex. Such an evolution is referred to as an "alkaline pathway".

In addition, concentration of magnesium also contributes in controlling the geochemical evolution of the solutions. In fact, magnesium can enter the composition through magnesium silicates (sepiolites, stevensite) or magnesium carbonates (magnesite, magnesian calcite) as is shown in Eq 1 and 2:

$$
\begin{gathered}
2 \mathrm{Mg}^{2+}+3 \mathrm{H}_{4} \mathrm{SiO}_{4} \square \mathrm{Mg}_{2} \mathrm{Si}_{3} \mathrm{O}_{7.5} \mathrm{OH} .3 \mathrm{H}_{2} \mathrm{O}+4 \mathrm{H}^{+}+0.5 \mathrm{H}_{2} \mathrm{O} \\
\mathrm{Mg}^{2+}+\mathrm{CO}_{3}^{2-} \square \mathrm{MgCO}_{3}
\end{gathered}
$$

In the crystallization reaction of sepiolite 4 protons $\left(\mathrm{H}^{+}\right)$are released, and they react with two carbonates to form water and carbon dioxide : $4 \mathrm{H}^{+}+2 \mathrm{CO}_{3}{ }^{2-} \rightleftarrows 2 \mathrm{CO}_{2}+2 \mathrm{H}_{2} \mathrm{O}$ Whereas during the precipitation of magnesite, each $\mathrm{Mg}^{2+}$ uses a carbonate $\mathrm{CO}_{3}^{2-}$; therefore it is useful to define an additional indicator, called the Residual Sodium Carbonate (RSC) sometimes referred to as Calcite+magnesite Residual alkalinity (RA calcite+magnesite) as is shown in Eq. 3: 


$$
\mathrm{RSC}=\mathrm{Alk} \cdot-(\mathrm{Ca}+\mathrm{Mg})\left(\mathrm{mmol}_{\mathrm{c}} \cdot \mathrm{l}^{-1}\right)
$$

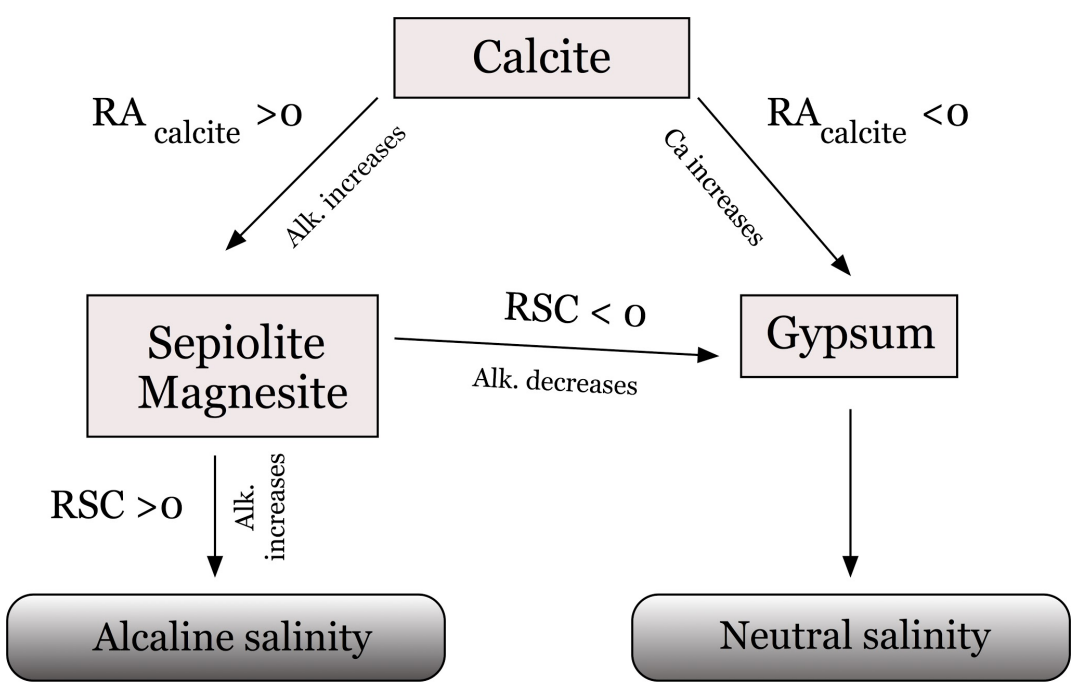

Fig. 3. Main chemical evolution processes for irrigation water

The evolution of the soil solution can be summarized by the diagram in Figure 3 where, depending on the values of the different indicators, it is possible to predict the type of salinity likely to affect an irrigated soil.

\section{Consequences on Soils}

Whether by dilution or by adsorption of monovalent cations (particularly sodium), when clays are dispersed, the aggregates slake/disperse and soil structure collapses, leading to adverse properties as follows:

- Soils have no structure and behave like mud or slurry when wet,

- Soils become extremely hard upon drying and are practically impossible to cultivate.

Moreover, dispersed clays, move, rearrange, and eventually clog the macropores and thus drastically reduce soil hydraulic conductivity. Conditions of oxygenation of the environment are then strongly disturbed and the good development of roots and therefore plants are affected. On the other hand, infiltration of water into the soil during irrigation or during rain events becomes extremely slow or 
almost impossible. Thus practicing agriculture becomes difficult, if not impossible, especially in areas with low technical and financial resources to rehabilitate or reclaim these soils.

It is therefore important to monitor the parameters that can lead to this catastrophic situation. For cultivated soils, sodium is usually responsible for these types of soil degradation. The Exchangeable Sodium Percentage (ESP) is therefore a particularly important indicator to follow. If ESP values are close to or more than $15 \%$, then the risk of clay dispersion and sodication is high.

\section{A complex physical framework}

\section{A. Late Holocene history}

The lower Senegal valley is characterized by a low altitude, since the sea level during the low water period reaches only $20 \mathrm{~m}$ in Kayes, a city currently located at $900 \mathrm{~km}$ from the river mouth. As a result, before the river regulation of 1986 and at the end of the dry season, saline water reached as far as the town of Podor, $215 \mathrm{~km}$ from the ocean. Such a topographical configuration motivated the construction of an anti-salt dam for the river management, but previously it led to sea water intrusion several times into the valley during the Quaternary period (Faure et al. 1980). The presence of saline soils observed in the middle valley has long been attributed to residual lenses of salt deposited by the sea. However, as will be discussed below, this assumption is not validated neither by the chemical profile of salinity, nor by its distribution in the landscape. Therefore, the origin of the salt and its distribution are much more complex. The most documented sea transgression is the Nouakchottian transgression that occurred in the middle Holocene, soon after $6000 \mathrm{BP}$, with a shoreline that reached about 1 to $3 \mathrm{~m}$ above the present sea level (Barusseau et al. 2007; Sarr, Sow, and Sarr 2008). Another short transgression up to $2 \mathrm{~m}$ is referred to as the Dakarian event at around $3000 \mathrm{BP}$. The last marine incursion started about 2000 years BP and ended about 680 BP. Mangrove vegetation grew in the fluviomarine environment. Then, during the last 600 years, the sea and the mangrove regressed from 
Boghé, located $380 \mathrm{~km}$ from the present coast, scanning the whole valley downriver to the present Senegal delta, where remnants of the mangrove vegetation are still present along small watercourses. Soil development from muddy sediments accompanied this regression. Thus, upriver soils, being the first to have been drained, are those with the most advanced development, whereas the soils in the delta show only a beginning of pedogenesis. In this context, soils of the lower valley of the Senegal River must be regarded as a chronosequence, which makes it possible to trace not only the gradual evolution of the soils from an unripe mud (Pons and Zonnefeld, 1965) to acid sulphate soils and finally to Vertisols, but also to follow the various processes of salt accumulation.

\section{B. Major processes of soil formation}

The mangrove vegetation that colonized the floodplain is a key indicator to understand soil formation and evolution. In the waterlogged environment around the mangrove roots, sulphur-fixing bacteria accumulated pyrite derived from inputs of seawater sulphate at each flood tide. Pyrite contents are usually between 1 and $2 \%$, although values up to $5 \%$ of the soil mass have been reported in the delta (Seiny Boukar 1983; Deckers et al. 1997). This mineral is a reservoir of potential acidity as long as the reduced state is maintained. The last regression, which started about 600 years ago, favoured oxidation, releasing strong acidity in the soil profile. The initial pyritic sediment is then transformed into acid sulfate soil through two major processes:1) an irreversible loss of water that strongly contributes to the ripening of the sediment, and 2), iron oxidation and the appearance of jarosite and then hydrolysis into hematite and goethite minerals from the bottom to the top of the profile (Barbiero et al., 2005). Then, a series of chemical reactions are induced, and are related to acid neutralization by the soil acid neutralizing capacity (ANC). The first neutralization of acidity is caused by the dissolution of the shells and other carbonates as is shown in Eq.4:

$$
\mathrm{CaCO}_{3}+4 \mathrm{H}^{+}+\mathrm{SO}_{4}{ }^{2-} \rightarrow \mathrm{CaSO}_{4}, 2 \mathrm{H}_{2} \mathrm{O}+\mathrm{CO}_{2}
$$


This reaction can be observed today in the delta, where shell layers (Anadara senilis fragments and Tympanotonus fuscatus shells) abruptly and laterally transform into gypsum that appears as nodules of a centimetre scale. Parallel to the dissolution of carbonates, the protonation of clay minerals (a mixture of kaolinite, smectite and illite) contributes to acid neutralization. The protonated clays are then destabilized by the penetration of protons into the octahedral layers by substituting aluminium ions, which are released from the network and adsorbed to the clay surface (van Breemen, Mulder, and Driscoll 1983; van Breemen 1988). Consequently, the Al no longer binds the tetrahedral layers and the constituent ions $(\mathrm{Si}, \mathrm{Al}, \mathrm{Fe}, \mathrm{Mg}, \mathrm{K} \ldots$...) are released into the sulphate-rich solution. The influence on the soil profiles is twofold. Various types of aluminium sulphates precipitate on the topsoil (Le Brusq et al. 1987) and a sandy horizon resulting from the residual accumulation of quartz is formed around $20 \mathrm{~cm}$ deep, progressively reaching down the soil profile (Furian et al. 2011). The above described reactions transform a soil profile initially consisting of an unripe mud with pyrite and carbonate shell beds into a sandy soil strongly colored by iron oxides and with gypsum horizons about 60 to $90 \mathrm{~cm}$ deep, with an amount of gypsum that depends on the antecedent amount of shells. These reactions can be grouped into a first soil transformation front (Fig. 4), which progressed downriver into alluvial deposits, accompanying the last marine regression from the area around Boghe to the present Senegal delta.

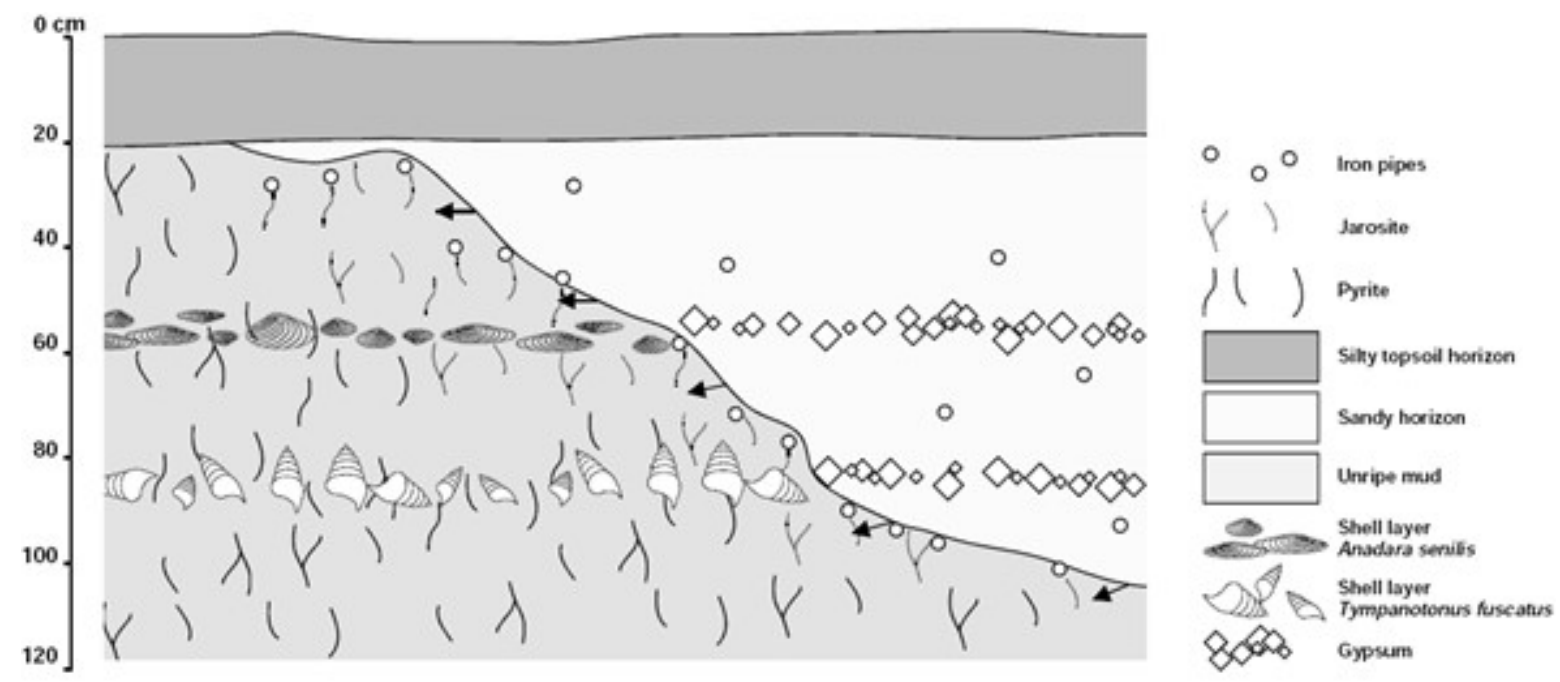

Fig. 4. Schematic description of the first soil transformation front in the Lower Senegal Valley. 
A second transformation front induced by the overflows of the Senegal River also impacts the soils in turn (Fig. 5). The river water has a typically continental chemical profile, with low mineral charge and neutral to slightly alkaline $\mathrm{pH}$. During floods, the water infiltrates the soils and comes into contact with acid solutions rich in iron, aluminium and silica. On contact between these two chemically contrasted environments, kaolinite precipitates, initially as clay laminae in the sandy horizon (Barbiero et al. 2005). Progressively, the acid conditions are sufficiently neutralized by the large amounts of basic cations present in the solution to allow the progressive appearance of a smectite of iron-beidellite type. Eventually, the clay precipitation results in the formation of a superficial clay horizon, which thickens laterally and also acquires vertic properties. The final soil profile consists of three main horizons of variable thickness, with, from top to bottom, a clay horizon with vertic properties, a sandy horizon with some clay laminae and an unripe mud with pyrite and jarosite. Such contrasting soil horizons with abrupt transition look like alluvial deposits and have therefore been interpreted stratigraphically by many authors as indicating changes in the sedimentation regime of the river (Michel 1973), however, they actually result from two successive soil transformation processes.
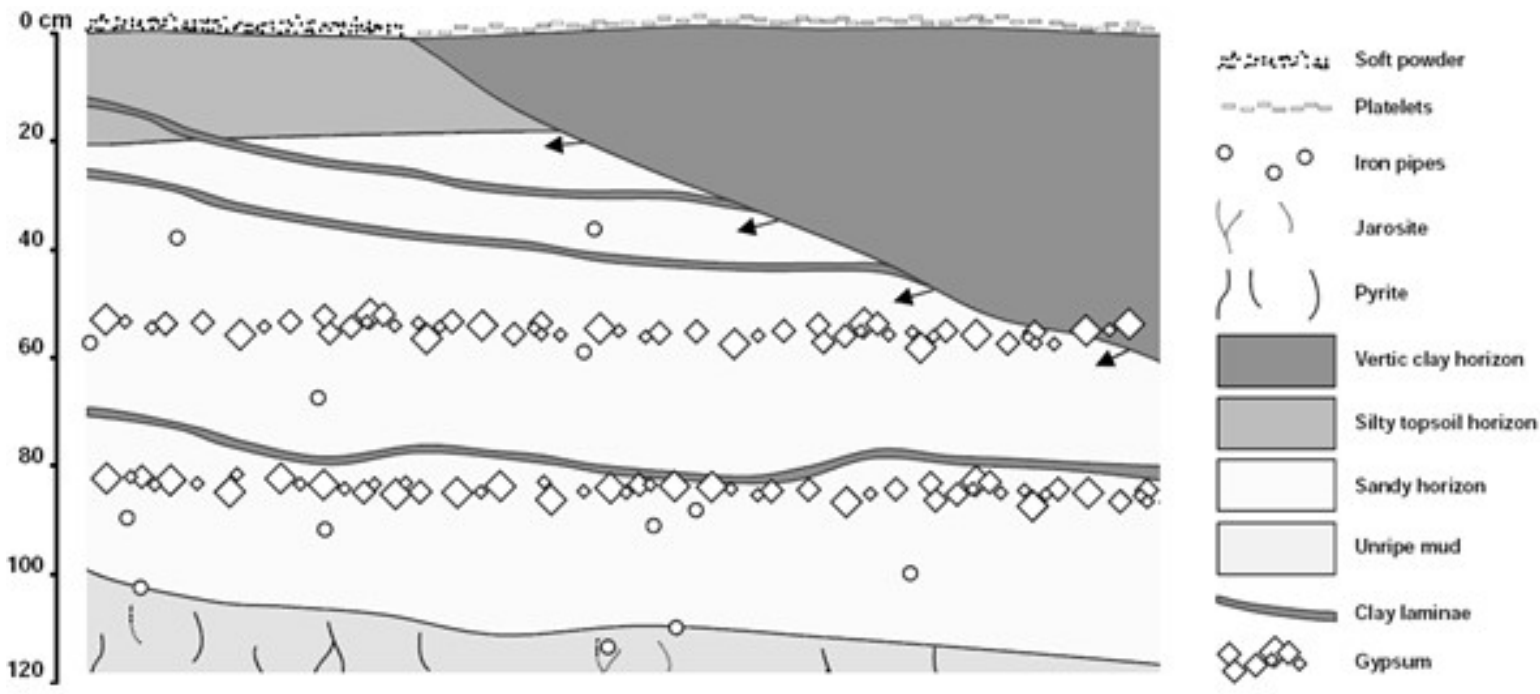

Fig. 5. Schematic description of the second soil transformation front in the Lower Senegal Valley. 


\section{Aeolian salt deposits}

The phenomenon of soft powder formation, consisting of silt and sand-sized particles, is caused by the rapid crystallization of salts, and is currently occurring in the delta. However, two cases should be distinguished: when wind deflation is active before the first transformation front, the precipitation sequence is gypsum $>$ halite (Mohamedou et al., 1999). The particles are therefore, mainly enriched with these two minerals. On the other hand, when the wind deflation is active after the first transformation front, pyrite oxidation has occurred and enriched the soil solution with sulphates. The precipitation sequence was changed to gypsum $>$ thénardite/mirabilite $>$ halite. Wind accumulations can then be relatively enriched in sodium sulphates. The deflated particles deposit behind any windbreaking obstacle and form saline lunettes usually referred as clay dunes. Because water courses, still occupied by the remnants of mangrove vegetation, are the main obstacles to prevailing winds from NE to NW, aeolian saline accumulation mainly occurs on their southern bank forming elongated clay dune deposits (Barbiero et al. 2001; Barbiero et al. 2004). The above described second transformation front matches with a change in the topsoil texture from 15 to $30 \%$ clay. It abruptly modifies the aspect of the soil surface from soft powder, vulnerable to aeolian deflation, to platelets less vulnerable to wind erosion. A laboratory outflow experiment (Wind 1968) was conducted on two topsoil blocks, collected a few meters apart on each side of this limit between the soft powder and the platelets. The results indicated that before the passage of this second transformation front, the solutes reached more easily to the surface of the soil where they precipitate causing a deflatable soft powdery structure. On the other hand, after the passage of the front, the change of texture in the topsoil horizon modifies the unsaturated water transfers, favouring the crystallization of the salts at a depth of about $3 \mathrm{~cm}$ below the surface, and causing the formation of platelets (Furian et al., 2011). These results showed that the second transformation front halts the process of wind deflation. As a result, deflation of saline particles and clay dune formation are now only observed in the lower delta (Barbiero et al., 1998), particularly in the Diawling National Park (Mauritania) downstream of the Diama dam. However, in the past, the second transformation front was located much further upriver, and wind deflation and salt particle accumulation could act on an area located upstream that has moved downstream over the past 600 years. 


\section{Saline areas in the lower valley}

To summarize, the soil formation in the valley has implemented two processes of salt accumulation. The first one is of sedimentary origin, generally at a depth of about 0.6 to $1.2 \mathrm{~m}$, and corresponds to the transformation of shell layers into gypsum. The chemical profile of this salinity is of $\mathrm{Ca}-\mathrm{SO}_{4}$ type. The quantity of salt depends on the initial quantity of carbonate shells. This salinity is referred to as "deep gypsum" furtherly in the text.

The second one is of an aeolian origin, i.e. a surface salinity that corresponds to the deposits of wind deflated saline particles. The chemical profile is primarily of $\mathrm{Na}-\mathrm{Cl}$ type, and secondarily of $\mathrm{Ca}-\mathrm{SO} 4$ and $\mathrm{Na}-\mathrm{SO}_{4}$ type. The thickness of the aeolian accumulations is variable, from a few centimetres to 1 m thick. It will be thereafter referred to as "aeolian salinity". In the Senegal middle valley, since the passage of these two above described transformation fronts, seasonal rains and river floods have contributed to the elimination of these two kinds of salt stocks, although these have interacted to control the presence and distribution of saline soil in the landscape.

A database collated from survey reports and other grey literature (mainly in French) shows that the general trend is a decrease in soil salinity towards upriver, in accordance with the chronosequence mentioned in [II.A.] (Barbiero et al. 2004). The aeolian salinity, initially in the topsoil, is translocated about 0.3 to $0.6 \mathrm{~m}$ down in the soil profile. Therefore, although the salts are not immediately detectable, farmers are locally confronted with the presence of saline soils, which are evident from the first crops after irrigation is started by remobilization of the salts into the surface layer. Many farmers have deserted their plots whose crops have been burnt by salinity. A key aspect for a successful implementation of irrigated agriculture is to detect where the saline areas are located in the landscape. The distribution of landscape units has changed considerably since the saline accumulations have ceased. The anastomosed meanders of the river have moved, some channels have been degraded, filled, some depressions have formed. Thus, it is not possible to relate the occurrence of salt to the present geomorphology in the valley. There are saline and non-saline river banks, saline and non- 
saline depressions ... On the other hand, saline areas are well correlated with a former geomorphology, which can usually be detected from aerial or satellite imagery. By using these tools, transects can be positioned for electromagnetic salinity surveys (Barbiero et al. 2001). Figure 6 [NGalenka] shows such a survey in the N'Galenka area together with the simplified geomorphology in the Podor region, where irrigated schemes have been implemented in the early 2000s.

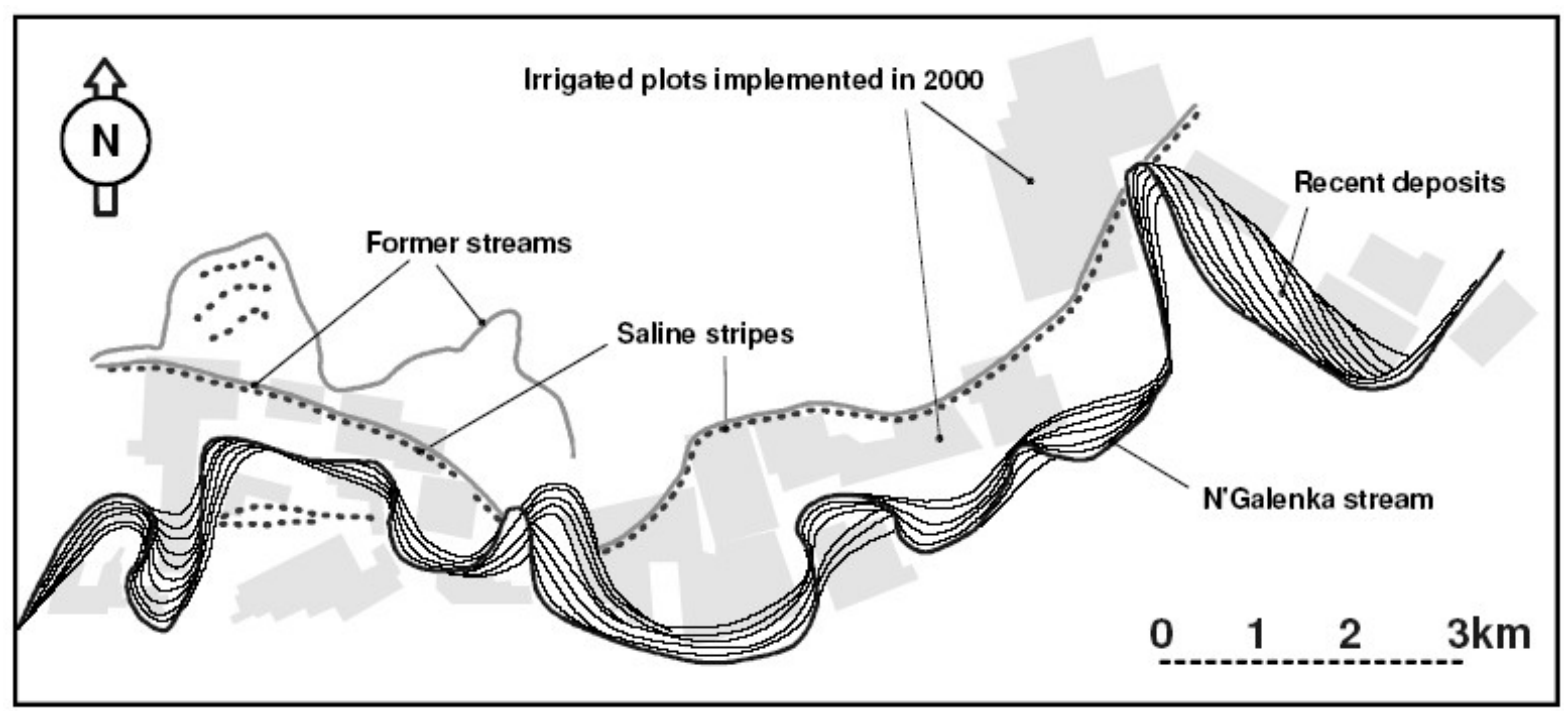

Fig. 6. Results of an electromagnetic survey in the N'Galenka area showing the distribution of salinity as stripes accompanying the former streams. Note that the salinity is intersected by the current N'Galenka stream and its recent deposits, attesting for an ancient salt accumulation.

The N'Galenka flows south of the area and its meanders intersect the bed of an ancient watercourse. The electromagnetic survey reveal that salinity is distributed as strips about 100-200 m wide and several kilometres long, mainly on the southern margin of the former channel, this distribution seems in agreement with the presence of former wind accumulations of salt. The study of the chemical profile of salinity, from concentration diagrams based on chloride ions, reveals that water was not the vector of this salt accumulation (Barbiero et al., 2004). Moreover, the chemical profile is predominantly of $\mathrm{Ca}-\mathrm{SO} 4, \mathrm{Na}-\mathrm{SO} 4$ and $\mathrm{Na}-\mathrm{Cl}$ type, although various intermediate chemical compositions between these three end-members have been detected, within a same saline area, and sometimes within a same soil profiles over short distances of about 0.2 to $0.3 \mathrm{~m}$. 
The distribution, morphology and chemical profile diversity of saline areas can be explained by the interactions between both, deep gypsum and aeolian salinity. Soil desalinization by rains and stream overflows has occurred before the river regulation, and is still occurring in the valley although with less intensity. In this framework, former clay dunes remained saline for a longer time for two reasons: first, they are on slightly higher ground and less vulnerable to desalinization during floods, and second, the initial amount of salt is usually higher than outside the deposit. In these clay dunes, by dissolving some superficial gypsum, soil water reaches saturation with respect to this mineral and therefore becomes non-aggressive when percolating through the deep gypsum that has remained in the soil profile. The deep gypsum began to dissolve only after almost complete elimination of the superficial aeolian salinity. In this context, former clay dunes are detected nowadays in the Senegal middle valley as saline areas with salts from two sources, and with amounts that depend on (i) the thickness of the aeolian deposit, (ii) the quantity of initial carbonate shells, and (iii) the progress of desalinisation.

\section{E. Conclusion}

The model of soil formation in the lower Senegal valley, which is summarized in Fig. 7, involved very powerful processes, initially supplied by extreme acidic geochemical conditions resulting from the oxidation of reduced iron minerals accumulated in the form of pyrite by tidal cycle in a waterlogged environment. The proposed model explains salt distribution, and the intensity and chemical variability of salinity (Furian et al., 2011). This diversity will be illustrated in the following examples, which corresponds to sites monitored under cultivated conditions for several years. Two main aspects will be developed: on the one hand the dynamics of salts after cultivation and on the other hand the secondary risk of soil degradation by alkalization under irrigated conditions with weakly mineralized Senegal river water, having a positive calcite residual alkalinity $\left(\mathrm{RA}_{\text {calcite }}>0\right)$, and thus a potential of alkalization. 


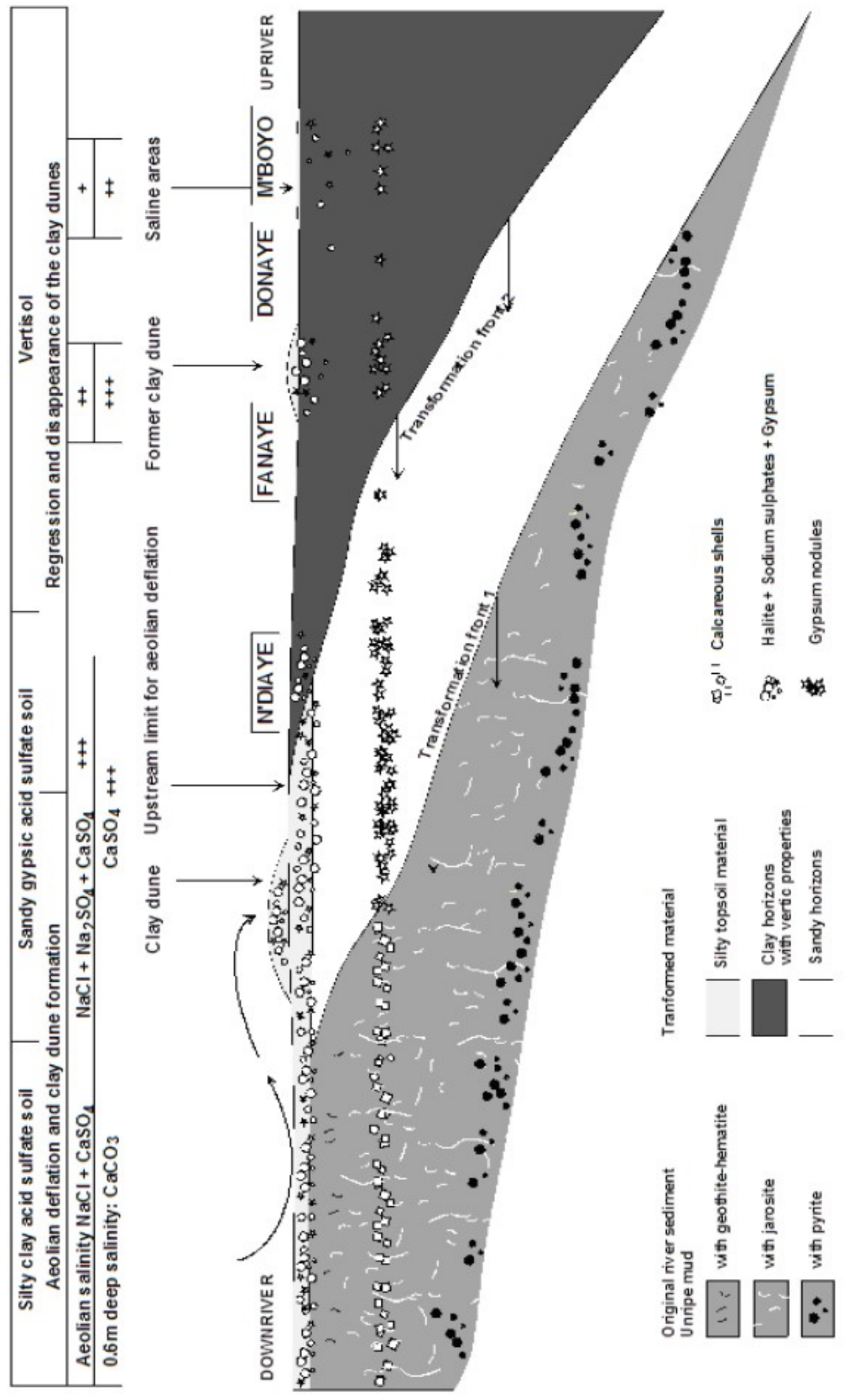

1. 
Fig. 7. Schematic evolution of the Senegal floodplain sediment and saline accumulation from the delta to the middle valley

\section{Evolution of soil and groundwater with irrigation}

\section{A. Study sites}

In this section, evolution of the quality of both groundwater and soils in irrigated conditions is discussed using several examples selected along the soil chronosequence. The selected experimental sites are N'Diaye, Fanaye, Donaye and M'Boyo located at 35, 165, 215 and $230 \mathrm{~km} \mathrm{~W}$ from the city of St Louis, respectively (Figs 1 and 7). In the Senegal valley, climate is characterized as Cape Verdean up to $30 \mathrm{~km}$ from the Atlantic coast because of maritime influences, and then as Sahelian in the more continental part. It is semiarid with an average yearly rainfall of about $220 \mathrm{~mm}$ concentrated during the rainy season from July to September. The dry season is comprised of a cool-dry period from October to February and a hot-dry period from March to June, during which dry warm wind from the Sahara desert (Harmattan) increase evaporation. Average Class A pan evaporation exceeds $2000 \mathrm{~mm}$ annually. The water chemistry was measured in the irrigation water, in the water table from piezometers installed in the plots, and in the soil solution from porous cups installed at $0.1,0.2,0.3$ and $0.6 \mathrm{~m}$ deep.

\section{The site of N'Diaye}

N'Diaye is an experimental site of AfricaRice (ex WARDA, West Africa Rice Development Association) in the Senegal delta, $35 \mathrm{~km}$ West of St Louis. It is located in a transition zone between the Cape Verdean and Sahelian climate. The overall topography is flat and before the river regulation, the area was prone to inundation by the floods. The typical soil profile of the N'Diaye site shows two very distinct superimposed materials. In the upper $0.6 \mathrm{~m}$, the soil profiles indicate a clayey, 
compact material with coarse prismatic to vertic structure, and a light brown color. Numerous iron pipes were observed from $0.5 \mathrm{~cm}$ downwards associated with coarse $(1 \mathrm{or} 2 \mathrm{~cm})$ gyspum nodules. In the soil beneath, the texture is sandy to sandy loam with marked hydromorphic features illustrated by a dominant grey color. Like most of the soils in the Senegal delta, the soil at Ndiaye is saline and generally acidic, due to remains of pyrite or by-products, as a result of the ancient mangrove vegetation. In particular, many pale yellow jarosite mottles can be observed below $0.8 \mathrm{~m}$ depth.

The saline water table is shallow; it can be observed at about $1 \mathrm{~m}$ depth in the absence of irrigation during the dry season, and reaches $0.4 \mathrm{~m}$ and $0.2 \mathrm{~m}$ during the irrigated cropping season in off-season and rainy period, respectively. The irrigation water is pumped from the Lampsar, a tributary of the Senegal river. The EC varies from 0.1 to $0.7 \mathrm{dS} . \mathrm{m}-1$ throughout the year. The chemical profile is $\mathrm{HCO}_{3} / \mathrm{Ca}-\mathrm{Mg}$ with a positive $\mathrm{RA}_{\text {calcite, }}$ but with a negative $\mathrm{RSC}$.

\section{The site of Fanaye}

On Fanaye site, paddy fields are irrigated with water pumped from the N'Galenka stream, another tributary of the Senegal River. N'Galenka water has a low mineral charge (EC of about $0.1 \mathrm{dS} . \mathrm{m}-1$ ) with a $\mathrm{Ca}-\mathrm{Mg}-\mathrm{HCO}_{3}$ chemical profile, a positive $\mathrm{RA}_{\text {calcite }}$ and also a positive $\mathrm{RSC}$ throughout the year. A risk of soil degradation by alkalization must, therefore, be carefully considered in irrigated plots. Measurements were conducted within a slight depression of approximately 30 ha, and such a situation favoured the development of the clayey horizons, down from the soil surface (second transformation front above described). The soils are Vertisols with 48 to $55 \%$ clay content, and are characterized by a gilgai microrelief on the surface formed by the prevalence of the wetting-drying cycles. The clay horizons constitute a $2 \mathrm{~m}$ thick homogeneous material overlying a sandy material, with an abrupt interface. The groundwater was not observed with auger sampling to $6 \mathrm{~m}$ depth. 


\section{The site of Donaye}

For several years, the plots of this site were generally cultivated with two crops of rice per year, sown during the hot dry season, from March to June, and the wet season from July to October. Paddy fields are flooded for more than 100 days during each growth cycle. However, during the study period, there were only rainy season crops, and no hot dry season crops. The soil is a Vertisol with a clay texture (> 65\% clay consisting of 70\% smectite and 30\% kaolinite, Boivin et al., 2002), a very marked vertic structure, abruptly overlaying a sandy material at about $1.2 \mathrm{~m}$ deep. The water table fluctuates between 1.2 and $2.5 \mathrm{~m}$ depth throughout the year and is characterized by a SO4-Cl/Na chemical profile. The irrigation water,supplied from the Senegal river, has a low mineral content with EC of about $0.06 \mathrm{dS} \cdot \mathrm{m}^{-1}$. RA calcite is positive, whereas RSC is usually slightly positive or close to zero.

\section{The site of M'Boyo}

The site of M'Boyo is on a 15 ha irrigated area developed by EDF (European Development Fund) and located on an island between the river Senegal and the Gayo, a distributary-tributary stream from the Senegal. The irrigation water is obtained from the Senegal river, just as is for the site of Donaye, and has the same chemical characteristics. The experimental plot was cultivated with rice crop during the wet season from August to November without any crop during the hot dry season. The soil profile of the M'Boyo site is similar to that of Donaye with $1.9 \mathrm{~m}$ of clay material (58 to $66 \%$ clay) abruptly overlaying a sandy material (about 1\% clay), strongly colored by iron oxides. The sandy horizons are 1.5 to $2 \mathrm{~m}$ thick. Below, there is a grey loamy sand material with some pyrite and jarosite minerals. In the experimental plot, the soils are saline and clearly show two saline horizons at $0.6 \mathrm{~m}$ and 1-1.2 $\mathrm{m}$ deep, with $\mathrm{Cl}-\mathrm{SO} 4 / \mathrm{Na}$ and $\mathrm{SO} 4 / \mathrm{Ca}$ chemical profile, respectively. These two saline levels are in accord with the model of salt accumulation presented in II.D. The first level may correspond to a transformation towards a salinity of aeolian origin to a depth of $0.6 \mathrm{~m}$, whereas the second level presents the characteristics of a deep gypsum accumulation from the transformation of a shell layer. 
The water table is very saline, with a mineral content similar to that of the sea water, and a chloride sodium chemical profile.

\section{Irrigation water}

The chemical composition of the irrigation waters used in the 4 sites, does not represent any risk to soil quality when plotted in the Riverside Salinity Lab diagram. However when simulating the concentration with PHREEQC (Parkhurst and Appelo 1999), the solution becomes extremely sodic, especially for the Senegal River water, used in Mboyo and Donaye (Figure 2).

\section{B. Soil and groundwater table evolution under irrigated crops}

\section{N'Diaye}

Evolution of soil solution chemistry in plots follows clear trends for all major elements, except for that of the alkalinity that show more scattered amounts along time. During the rainy season, $\mathrm{Na}, \mathrm{Ca}$, $\mathrm{Mg}, \mathrm{K}, \mathrm{SO}_{4}$ and $\mathrm{Cl}$ contents in soil solution increase at all depths. However, the soil is more saline at depth than at the surface. Consequently, this saline profile is not due to a concentration process driven by evaporation, but is caused by the rise of the saline water table under the influence of the Senegal River flood, which is confirmed by the piezometric measurements. During the off-season crops, the salinity gradient remains unchanged, but soil solution concentration declines at all depths. Salts are leached downwards, during the drawdown of the water table. The chemistry of irrigation water is dominated by carbonates, and this chemical form dominates in surface water, and in the most superficial soil solution, up to $10 \mathrm{~cm}$ deep. Underneath, the soil solution has low alkalinity. Alkalinity concentration varies during the year, namely with local temporary decline during the rainy season. This response of the alkalinity is attributed to the rise of the water table with a more acidic composition during the rainy season. Indeed, at this site potential soil acidity derived from the mangrove deposits has not yet been completely evacuated: the oxidation pyrite and hydrolysis of 
jarosite during the intercropping periods when the water table is low, releases $\mathrm{H}+$ ions which are transferred to root zone during the rise of the groundwater during the rainy season (Fig. 8).

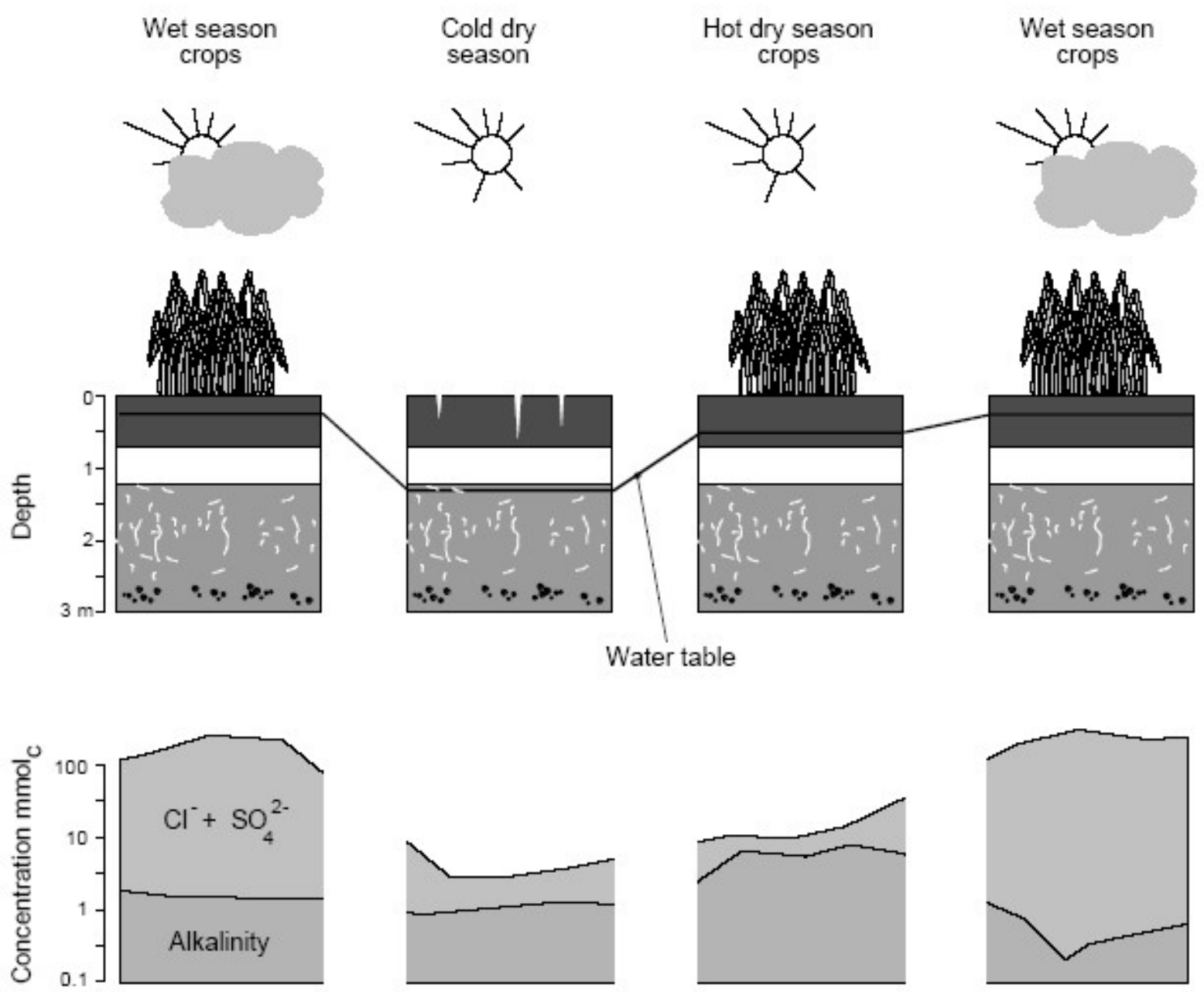

Fig. 8. Evolution of groundwater level and soil solution chemistry at $0.3 \mathrm{~m}$ depth during the different seasons at the NDiaye site. Note the synchronous movements of salts with the water table.

\section{Fanaye}

At the site of Fanaye, located further upstream than N'Diaye, the natural soil desalinization process is more advanced. Although located close to the meanders of the Senegal River (less than $2 \mathrm{~km}$ ), the groundwater could not be reached up to a depth of $6 \mathrm{~m}$ (Fig. 9). The absence of a shallow water table 
allows irrigation water to infiltrate deeper into the soil, avoiding excessive accumulation of carbonate salts brought by irrigation during the inter-cultivation periods. The soil solutions have moderate electrical conductivity (total concentration) but are in equilibrium with calcite, and $\mathrm{pH}$ is maintained at around 8.5. As $90 \%$ of the cation exchange capacity is saturated with $\mathrm{Ca}$ and $\mathrm{Mg}$, these elements buffer the soil solution, by limiting the increase in carbonate alkalinity and $\mathrm{pH}$. Neither the current salinisation nor alkalisation are threat to soil quality on this site. Moreover considering the thickness of the vertic clayey horizons and the buffer capacity of soil, on short to mid-term basis, irrigation does not pose any threat to soil quality.

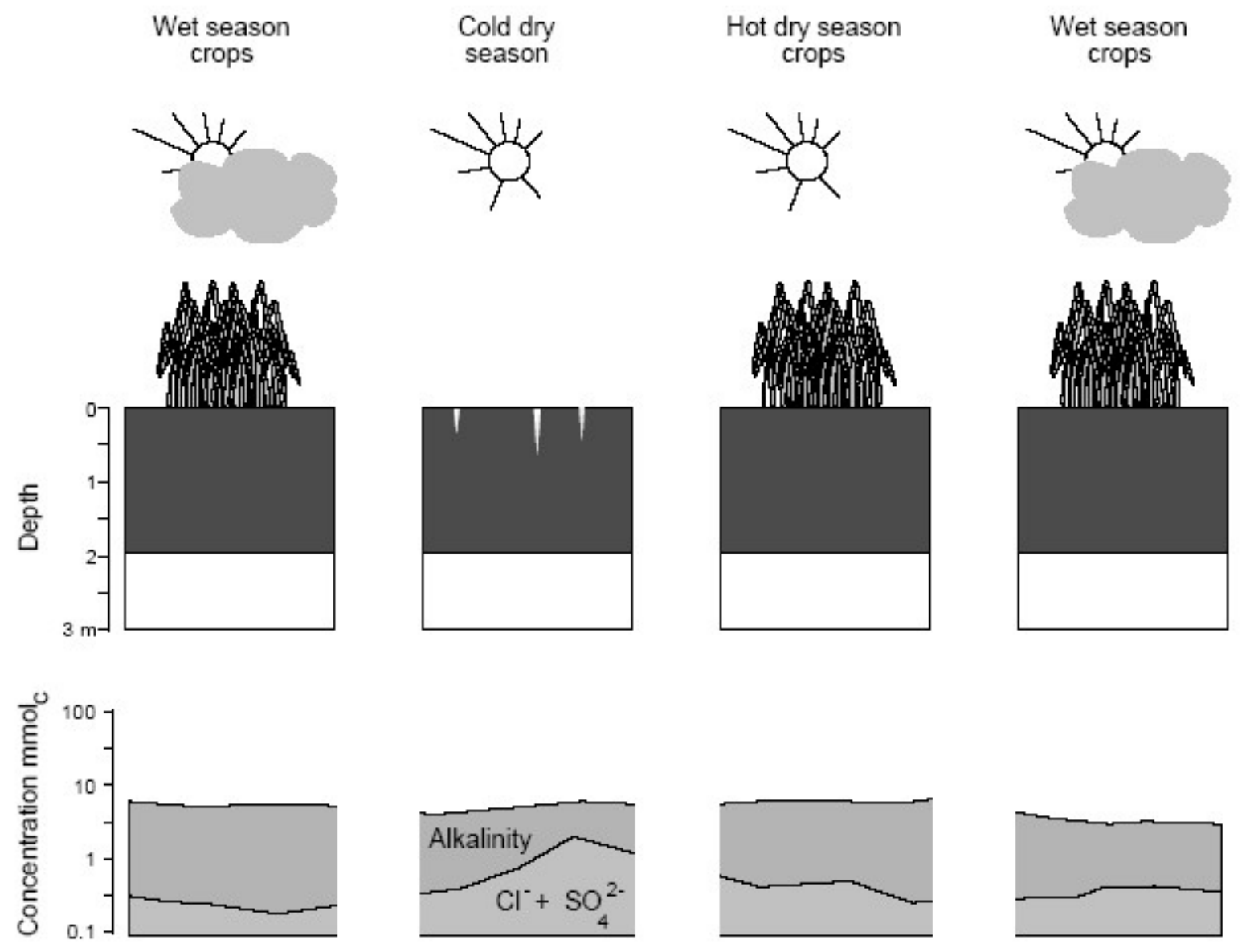

Fig. 9. Evolution of soil solution chemistry at a depth of $0.3 \mathrm{~m}$ during the different seasons at the Fanaye site. On this site, the desalination process is the most advanced. 


\section{Donaye}

As the site is located several meters above the River level, the groundwater is partly supplied by the irrigation canal and by the River, the water table fluctuates by about 3m (Fig. 10).

Two distinctive chemical profiles are represented in the soil solution. Near the soil surface, it has a calcium-magnesium/carbonate profile, whereas at depth the chemical profile is clearly chloride sulphate sodium. In the upper part of the soil, the alkaline chemical profile predominates during the cropping season, especially since the water infiltration is impeded by the entrapped air caused by submersion irrigation (Hammecker et al. 2003).

Calcium is controlled by precipitation as calcium carbonate that accumulates in the $0.6 \mathrm{~m}$ upper part of the soil after the cropping cycles. The soil solutions are saturated with respect to calcite, but despite the presence of the sulphate in groundwater, equilibrium with gypsum is not reached. Locally, remains of pyrite and jarosite contribute to acidification when oxidized and hydrolyzed and control the $\mathrm{pH}$ of the soil solution. Fe-minerals oxidation and acidification of soil solution at depth appear to be more pronounced during the years without off-season crops, while the water table level is lower. Moreover, the high CEC of the clay layer $(>35 \mathrm{mmolc} / \mathrm{Kg}$ ) is primarily saturated with $\mathrm{Ca}$ and $\mathrm{Mg}$ and represents a huge buffer controlling sodication avoiding a further evolution towards the alkaline pole. 


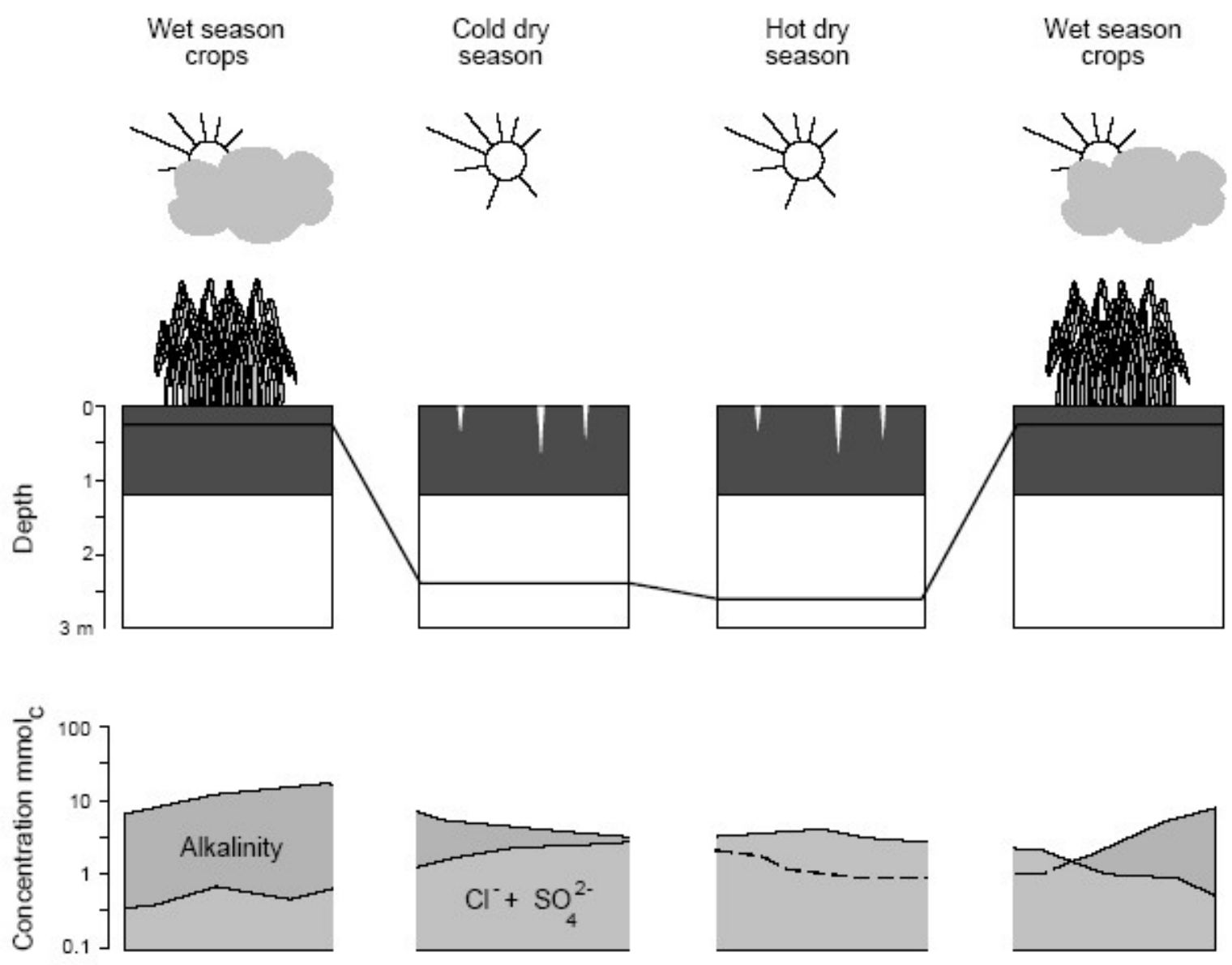

Fig. 10. Evolution of groundwater level and soil solution chemistry at $0.3 \mathrm{~m}$ depth during the season at the Donaye site.

\section{M'Boyo}

At the site of M'Boyo, the flow regime of the river seems to play a major role on the evolution of the water table. Indeed, the rise of the water table starts with high river flow, before irrigation. Similarly, the water table starts to draw down with the flood recession, while the plots are still immersed. The water table fluctuates by about 1 to $1.5 \mathrm{~m}$. The river flooding also impacts the chemistry of the water table, causing a decrease of the total concentration but an increase in alkalinity and $\mathrm{pH}$. The effect of this process decreases with the increase in distance to the river. The aquifer is saline and at equilibrium with gypsum, and therefore, has a little risk of saline accumulations to about $1.2 \mathrm{~m}$ of 
depth. In part of the irrigated perimeter closest to the river, dilution causes a temporary undersaturation with this mineral associated with a rise in the water table. It is therefore, in these plots closest to the river that the elimination of deep gypsum is possible. As in the case of the Donaye site, the influence of irrigation is negligible on the chemistry of aquifers. Though soil solution at M'boyo is concentrated below $60 \mathrm{~cm}$, it remains much less mineralized at $30 \mathrm{~cm}$ (Fig. 11) and soluble salts don't precipitate at the soil surface even during the dry season. In fact, self-mulching (Grant and Blackmore, 1991), rather common in clay soil, impedes evaporation front from reaching the soil surface and, therefore, prevents the soil solution to concentrate sufficiently to allow saturation of gypsum or halite. On the other hand, flooding during the rainy season or irrigation during the dry season, drains these soluble salts downwards, in a generalized desalinization dynamics (Figure 11).

$\begin{array}{cccc}\begin{array}{c}\text { Wet season } \\ \text { crops }\end{array} & \text { Cold dry } & \text { Hot dry } & \text { Wet season } \\ \text { season } & \text { season } & \text { crops }\end{array}$
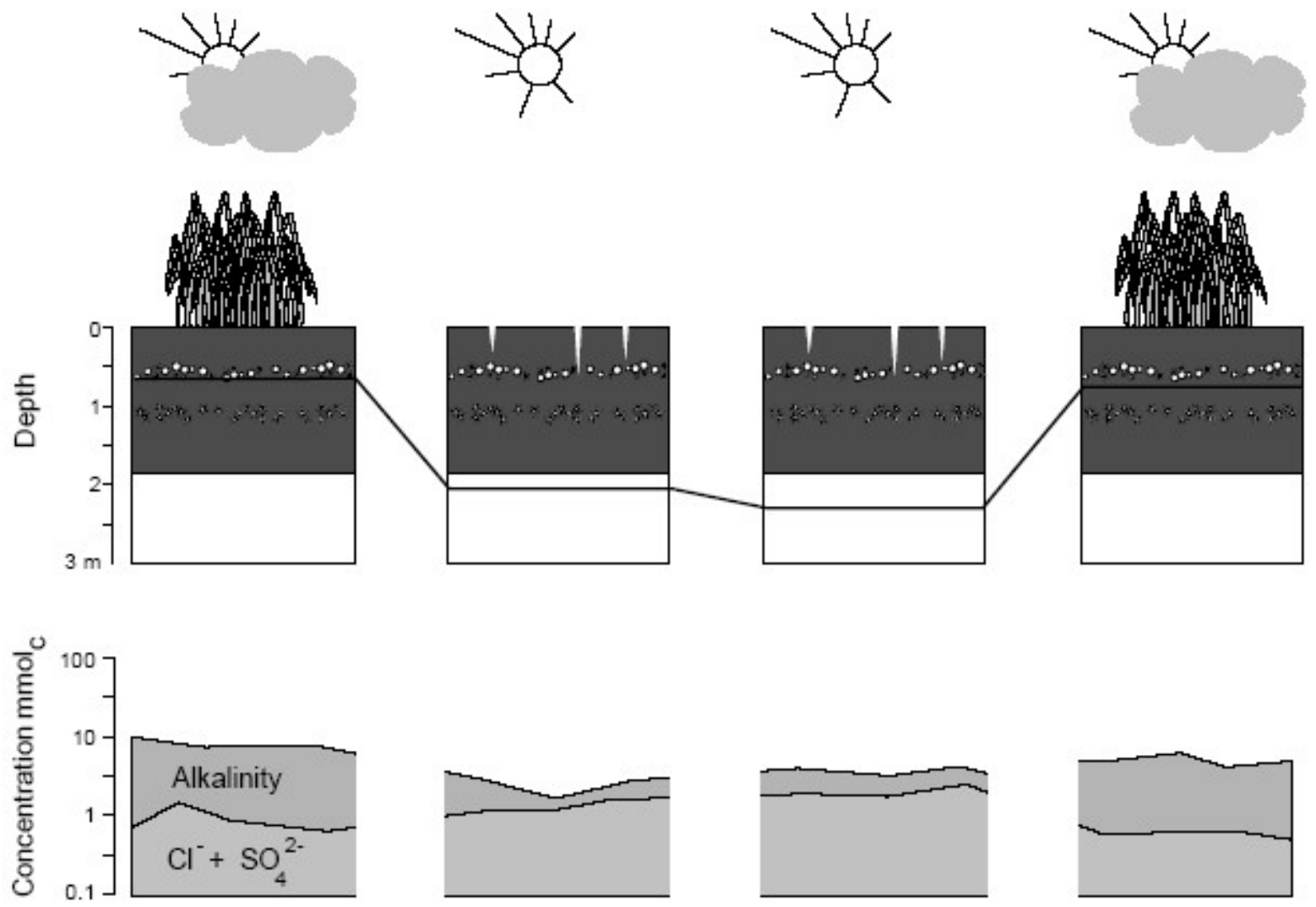
Fig. 11. Evolution of groundwater level and soil solution chemistry at $0.3 \mathrm{~m}$ depth during the season at the M'Boyo site. Note that despite the presence of salt accumulation at a depth of $0.6 \mathrm{~m}$, the soil solution concentration at $0.3 \mathrm{~m}$ remains moderate.

\section{Conclusion}

The four sites under study have distinct hydrodynamic and chemical conditions. In the delta, the N'Diaye site is characterized by the presence of a saline water table close to the surface and whose chemical property is strongly influenced by the various processes of neutral salt accumulation described in the [second part] $\left(\mathrm{Ca}-\mathrm{Na} / \mathrm{Cl}-\mathrm{SO}_{4}\right)$. In the short to medium term, the Lampsar irrigation water, whose alkalinization potential is limited, has no effect on the chemical evolution of the irrigated profiles. Irrigation merely leads to mechanically raising of the water table level. Neutral salts move upwards towards the top of the soil profile during the rainy season when the water table rises, but are leached downwards during the drawdown of the groundwater in the dry season. Alkalinity from the irrigation water is counteracted by the potential acidity liberated during the dry season when pyrite oxidizes and/or jarosite hydrolyses, and rises with the water table during the rainy season. The Fanaye site is located further upriver and on the left bank of the Senegal valley. Despite the use of an alkaline water for irrigation, the absence of water table allows the solutions to percolate down the soil profiles, and the strong cation exchange capacity mainly saturated with $\mathrm{Mg}$ and $\mathrm{Ca}$, avoids the risk of alkalization on the short term. The Donaye site, unlike in the previous other sites, evolution of the chemistry of soil solution in the topsoil is disconnected from groundwater. The presence of trapped air in soil physically separates two geochemical pools. A stock of calcite forms in the upper part of the soils under the influence of both the alkalinity of irrigation water, and the calcium from remnants of deep gypsum and/or aeolian salinity. This stock of calcium carbonate is the result of irrigation cycles imposed on these plots. Both, the rise of the water table with neutral saline properties and the strong exchange capacity of these soils, acting as a chemical buffer, limit the risks of the alkalization process. However, since the reserve of neutral saline solutions tends to be evacuated during the rainy 
season floods, the soil solution will evolve towards an alkaline chemical profile, with a risk of alkalization in the long term. The salinization in the M'Boyo site is essentially driven by the mobilization of significant ancient salt deposits (a mixture of aeolian salinity and deep gypsum accumulation) by the water table fluctuations governed by-the Senegal River. Irrigation has little influence on saline dynamics in this site.

\section{General conclusion}

Recent history of the valley of River Senegal is complex and marked by several sea intrusions during the Late Holocene period. The development of mangrove vegetation and the oxidation of soils following the last regression have led to the formation of acidic conditions that are the driving force not only for soil formation from freshly deposited muddy sediments, but also for two different processes of salt accumulation. One process generated salinity from the transformation of shell layers into gypsum, whereas another kind of salinity was caused by wind accumulated of saline particles as clay dunes. The river regime was regulated about thirty years ago by the construction of two dams, one upstream in Mali used as a water reservoir (Manantali), the other in the delta aimed at blocking marine intrusions (Diama). This development increased salinity in the Diawling National Park in Mauritania downstream of the Diama Dam, but also favored the development of irrigated agriculture in the middle valley. Initially, the presence of these salts, at least in appearance randomly distributed in the landscape of the middle valley, worried the farmers during the first years of irrigation, because of remobilization of these soluble salts towards the surface soil, mainly in vegetable crops which don't use enough water to drain the salts deep into the soil profile. Data from the downstreamupstream soil distribution as chronosequence show that the natural dynamics before the regulation of the river was a gradual elimination of the salts, mainly during the floods. Moreover, the monitoring of the few sites presented shows that this dynamic continues under irrigated conditions, mainly in submerged paddy fields. Water in the Senegal River has low salt concentration but presents a 
potential risk for soil alkalization. The composition of this water is similar to that of the Niger River, which led to soil alkalization in the interior delta in Mali and on the alluvial terraces in Niger. However, in the case of the Senegal Valley, this risk is minimal mainly for three reasons: (i) a reserve of potential acidity in soils, which is still available in the most downstream parts of the valley and in the delta; (ii) the presence of neutral salts inherited from former marine deposits and related accumulation processes, and (iii) clayey soils with high $\mathrm{CEC}$ and saturated with $\mathrm{Ca}$ and $\mathrm{Mg}$, a consequent reserve to restore equilibrium with the carbonates in the soil solution, that drastically slows down any alkalization process, especially with an adequate and judicious water management in the plots (Hammecker et al., 2009).

The presence of clayey soils in the Senegal River valley, contributed physically to limit the surface evaporation by self-mulching. Therefore, soluble salts (gypsum or halite) did not concentrate in the soil surface during the dry season and show typical efflorescences, unlike in more silty soils.

\section{References}

Barbiero, Laurent, Sébastien Cunnac, Landing Mané, Caroline Laperrousaz, Claude Hammecker, and Jean Luc Maeght. 2001. "Salt Distribution in the Senegal Middle Valley Analysis of a Saline Structure on Planned Irrigation Schemes from N'Galenka Creek.” Agricultural Water Management 46 (3): 201-13. doi:10.1016/S0378-3774(00)00088-3.

Barbiero, Laurent, Abdallahi Ould Mohamedou, Caroline Laperrousaz, Sônia Furian, and Sébastien Cunnac. 2004. "Polyphasic Origin of Salinity in the Senegal Delta and Middle Valley." Catena 58 (2): 101-24. doi:10.1016/j.catena.2004.03.003.

Barbiero, Laurent, Abdallahi Ould Mohamedou, Lucien Roger, Sônia Furian, Alain Aventurier, Jean Claude Rémy, and Serge Marlet. 2005. "The Origin of Vertisols and Their 
Relationship to Acid Sulfate Soils in the Senegal Valley." Catena 59 (1): 93-116. doi:10.1016/j.catena.2004.05.007.

Barusseau, Jean-paul, Robert Vernet, Jean-françois Saliège, and Cyr Descamps. 2007. "Late Holocene Sedimentary Forcing and Human Settlements in the Jerf El Oustani - Ras El Sass Region ( Banc d'Arguin , Mauritania )." Géomorphologie: Relief, Processus, Environnement 13: [On line]. doi:10.4000/geomorphologie.634.

Boivin, P., Favre, F., Hammecker, C., Maeght, J. L., Delariviere, J., Poussin, J. C., Wopereis, M. C. S. 2002. Processes driving soil solution chemistry in a flooded rice-cropped vertisol: analysis of long-time monitoring data. Geoderma. 110: 87-107

Breemen, N van. 1988. "Effects of Seasonal Redox Processes Involving Iron on the Chemistry of Periodically Reduced Soils.” In Iron in Soils and Clay Minerals, edited by J W Stucki, B A Goodman, and U Schwertmann, 797-809. Dordrecht: Springer Netherlands. doi:10.1007/978-94-009-4007-9_23.

Breemen, N van, J Mulder, and C T Driscoll. 1983. “Acidification and Alkalinization of Soils.” Plant and Soil 75 (3): 283-308. doi:10.1007/BF02369968.

Le Brusq, J-Y, J-Y Loyer, B Mougenot, and M Carn. 1987. "Nouvelles Paragenèses À Sulfates D’aluminium, de Fer, et de Magnésium, et Leur Distribution Dans Les Sols Sulfatés Acides Du Sénégal.” Science Du Sol 25: 173-84.

Deckers, J, S Dondeyne, L Vandekerckhoven, and D Raes. 1997. "Major Soils and Their Formation in the West African Sahel." In Irrigated Rice in the Sahel: Prospects for Sustainable Development, edited by K M Miézan, M C S Woperies, M Dingkhun, J Deckers, and T R Randokph, 23-35. Saint Louis, Senagal: West Africa Rice Development Association (WARDA/ADRAO).

Faure, H, J C Fontes, L Hebrard, J Monteillet, and P A Pirazzoli. 1980. "Geoidal Change and Shore-Level Tilt Along Holocene Estuaries: Sénégal River Area, West Africa." Science 210 (4468): 421 LP-423. http://science.sciencemag.org/content/210/4468/421 .abstract. 
Furian, S., Mohamedou, A. O., Hammecker, C., Maeght, J. L., and Barbiero L., 2011. Soil Cover and Landscape Evolution in the Senegal Floodplain: A Review and Synthesis of Processes and Interactions during the Late Holocene. European Journal of Soil Science 62 (6): 902-12. doi:10.1111/j.1365-2389.2011.01398.x.

Grant, C. \& Blackmore, A. 1991. Self mulching behavior in clay soils - Its definition and measurement. Soil Res., 29, 155-173

Hammecker, C.; Antonino, A.; Maeght, J. \& Boivin, P. 2003. Experimental and numerical study of water flow in soil under irrigation in northern Senegal: evidence of air entrapment. European Journal of Soil Science, 2003, 54, 491-503

Hammecker, C.; van Asten, P.; Marlet, S.; Maeght, J.-L. \& Poss, R. 2009. Simulating the evolution of soil solutions in irrigated rice soils in the Sahel. Geoderma, 150, 129-140

Hammecker, C.; Maeght, J.-L.; Grunberger, O.; Siltacho, S.; Srisruk, K. \& Noble, 2012.

"Quantification and modelling of water flow in rain-fed paddy fields in NE Thailand: Evidence of soil salinization under submerged conditions by artesian groundwater" Journal of Hydrology, 456 457, 68 - 78

Michel, P. 1973. Les Bassins Des Fleuves Sénégal et Gambie : Étude Géomorphologique. Mémoires ORSTOM nº63.

Mohamedou, A.O., Aventurier, A., Barbiéro, L., Caruba, R., Valles, V., 1999. Geochemistry of clay dunes and associated pan in the Senegal delta (Mauritania). Arid Soil Research and Rehabilitation 13: 265-280.

Parkhurst, D.L., Appelo, C.A.J., 1999. User's guide to PHREEQC (version2)-a computer program for speciation, batch-reaction, one-dimensional transport, and inverse geochemical calculations. Water-Resources Investigations Report 99-4256 USGS, Denver, Colorado

Richards, L.A. (ed.) 1954. Diagnosis and improvements of saline and alkali soils. USDA. Agriculture Handbook 60. 160 p. 
Sarr, R., Sow, El H., and Sarr, B., 2008. "Holocene Marine Intrusions in Retba and Mbawane Lakes (Senegal) Evidenced by Ostracod Faunas.” Revue de Micropaléontologie 51 (4): 327-38. doi.org/10.1016/j.revmic.2007.03.002.

Seiny Boukar, L. 1983. “Etude Pédologique de La Cuvette de N’Der, Lac de Guiers (Région Du Fleuve Sénégal).” Dakar. 